\title{
Antúfouling Properties of Glass Substrates Irradiated with Acetylene Plasma
}

\author{
Meliton R. Chiong III, ${ }^{a}$ Ma. Cecilia M. Angub, ${ }^{a}$ \& Magdaleno R. Vasquez, Jr.b, \\ aMaterials Science and Engineering Program, College of Science, University of the Philippines, \\ Diliman, Quezon City 1101, Philippines; 'Department of Mining, Metallurgical, and Materials \\ Engineering, College of Engineering, University of the Philippines, Diliman, Quezon City 1101, \\ Philippines
}

*Address all correspondence to: Magdaleno R. Vasquez, Jr., DMMME Bldg., Velasquez St. cor. C.P. Garcia Ave., UP Diliman, Quezon City 1101, Philippines; Tel.: +63 2981 8500, x3132, E-mail: mrvasquez2@up.edu.ph

\begin{abstract}
Carbon films were grown on glass substrates via 13.56-MHz radio frequency (RF) plasma deposition at 1-, 3-, and 5-min deposition times. Admixtures of argon (Ar) and acetylene $\left(\mathrm{C}_{2} \mathrm{H}_{2}\right)$ plasma were used with working pressure of $100 \mathrm{~Pa}$ and RF power of $50 \mathrm{~W}$. The surface of the glass substrates was pretreated with hexamethyldisiloxane to improve film adhesion. Water contact angle and surface free energy of the glass surface significantly decreased on deposition of $\mathrm{C}_{2} \mathrm{H}_{2}$, indicating a hydrophobic surface. Fourier-transform infrared spectroscopy and Raman spectroscopy showed the presence of carbon moieties on glass, where the optimum carbon deposition was found at 3-min deposition time. The glass specimens were then subjected to a biofilm assay using Pseudomonas aeruginosa, where the number of adhered cells significantly decreased on the plasma-treated substrates. This study illustrated the potential application of carbon films deposited via RF plasma for antifouling applications.
\end{abstract}

KEY WORDS: plasma, carbon film, biofilm, antifouling

\section{INTRODUCTION}

Bacterial adhesion, which leads to biofouling, has been a widespread problem in the operation of various surfaces and equipment. This has resulted in additional expenses in terms of cleaning and maintenance among affected industries such as maritime, food, water systems, and healthcare. ${ }^{1}$ Biofilms also contribute to nosocomial illness such as healthcare-associated infections. ${ }^{2}$ These infections are one of the leading causes of patient death and morbidity within $48 \mathrm{~h}$ of hospitalization. ${ }^{2}$ Studies showed that from $3 \%$ to $5 \%$ of patients contract this type of infection after leaving the hospital. ${ }^{2,3}$ Bacterial biofilms may lead to chronic infections such as pneumonia, wounds, otitis media, and even medical implant infections that can lead to death. ${ }^{4,5}$ Thus, surfaces that can inhibit biofilm formation and bacterial contamination can be usefully applied in various fields.

Biofilms that are comprised of bacteria that adhere onto surfaces are surrounded by a matrix of organic polymers ${ }^{6}$ that are often the preferred mode of growth for most bacteria. ${ }^{7}$ Adhered bacteria are able to concertedly act through the production of signal molecules that affect their growth after reaching a certain quorum population through a 
mechanism called quorum sensing. ${ }^{8}$ Quorum sensing is a community genetic regulation mechanism that controls microbiological functions in response to population density. ${ }^{9}$ A study by Bakke et al. showed that the human pathogen Pseudomonas aeruginosa regulates virulence through quorum sensing. ${ }^{10}$ Disrupting this communication pathway and bacterial surface adhesion can thus be a potential target for preventing diseases and adverse environmental problems induced by biofouling.

Survival of a bacterium starts with adhesion that allows it to leech onto its surroundings and obtain nutrients therein. ${ }^{11}$ After the initial attachment, the development of a biofilm occurs on a structured community of bacterial cells enclosed in a self-produced polymeric matrix adherent to an inert or living surface. ${ }^{12}$ Bacteria may be free floating or surface bound. However, it is known that sessile bacteria are more resistant to antimicrobial agents than planktonic bacteria. ${ }^{1}$

The formation of the bacterial colony starts with its adsorption on a conditioning film composed of organic molecules. The bacteria slowly approach the film using a flagellar motion and analyze the site to determine its suitability for adhesion. They can then bind onto the surface and release an extracellular polymeric substance as the matrix multiplies and stabilizes to form a three-dimensional biofilm. ${ }^{13}$ The main functions of the biofilm matrix are to serve as an impermeable barrier against phagocytes and aid in resisting the desiccation process from occurring within the film. Control over the biofilm system can be ensured through their exchange of molecular signals at a close distance. Overall, the strength of the biofilm is dependent on the structure of the formed conditioning film. ${ }^{14}$

Surfaces such as glass, stainless steel, and rubber can be contaminated by the adhesion of microorganisms that initiate cellular growth leading to biofilm formation. ${ }^{15}$ The mechanism and factors affecting bacterial adhesion are very complex. ${ }^{16,17}$ Surface properties such as roughness, contact angle, and surface free energy (SFE) can affect cellular growth. ${ }^{18}$ Glass has high surface energy of $\sim 83 \mathrm{mN} / \mathrm{m}$, which is much greater than the $20-30-\mathrm{mN} / \mathrm{m}$ range in which bacterial adhesion is minimal. ${ }^{19}$ Wei et al. suggested that smoother surface, lower contact angles, and higher SFE are favorable for cell growth. ${ }^{18}$

Current research uses antibiofouling films that impede bacterial growth. Pavlukhina et al. developed a highly efficient, biocompatible surface coating that disperses bacterial growth through enzymatic cleavage of the extracellular matrix. ${ }^{20}$ Sahal et al. also observed antibiofilm properties of nanometer-scale silver coatings on glass and polysterene surfaces against human pathogens. ${ }^{21}$ Inclusion of silver nanoparticles in a composite coating also inhibited bacterial growth. ${ }^{22}$ Sun and Chen developed a low-temperature plasma coating of organo-silicon or organo-silicon/oxygen that also hinders biofilm formation. ${ }^{23}$

In this work, we investigated the modification of surface properties of glass using an admixture of argon (Ar) and acetylene $\left(\mathrm{C}_{2} \mathrm{H}_{2}\right)$ gas discharges. Growth of carbon-based films on the pretreated glass surfaces was characterized to include antibiofouling properties using $P$. aeruginosa as the biofilm-forming bacterium. 


\section{MATERIALS AND METHODS}

\section{A. Surface Pretreatment}

Soda-lime glass substrates were cut into $1 \times 2$-cm sizes and were subjected to a standard degreasing procedure. Before deposition, the glass surfaces were modified with hexamethyldisiloxane (HMDSO) to improve adhesion of the substrate to the grown film. We added $1.5 \mathrm{~mL}$ of HMDSO to a solution containing $135 \mathrm{~mL}$ methanol and $15 \mathrm{~mL}$ deionized water. We then added five drops of glacial acetic acid and stirred the solution for $30 \mathrm{~min}$. The glass substrates were fully immersed vertically for $30 \mathrm{~min}$. Finally, the glass substrates were rinsed with deionized water and oven-dried for $1 \mathrm{hr}$ at $110^{\circ} \mathrm{C}$.

\section{B. Plasma Deposition}

To deposit the films, we used a 13.56-MHz radio frequency (RF) capacitively coupled plasma reactor. The system is composed of a $165-\mathrm{mm}$ diameter bell jar evacuated by a rotary pump down to $8 \mathrm{~Pa}$. Before deposition, the system was cleaned using an $\mathrm{Ar}$ gas discharge. Once the glass substrates were loaded and base pressure was achieved, commercial-grade $\mathrm{C}_{2} \mathrm{H}_{2}$ was introduced into the chamber. We set the total working pressure at $100 \mathrm{~Pa}$ with a $\mathrm{C}_{2} \mathrm{H}_{2}$ :Ar pressure ratio of 5:95. RF power was set at $50 \mathrm{~W}$, and deposition times varied from 1 to $5 \mathrm{~min}$. After deposition, the samples were stored for characterization and biofilm assay.

\section{Thin-Film Characterization}

Contact angle measurements were carried out via a sessile drop method using 5- $\mu \mathrm{L}$ deionized water $\left(\mathrm{H}_{2} \mathrm{O}\right)$ and diiodomethane $\left(\mathrm{CH}_{2} \mathrm{I}_{2}\right)$ for both pristine and deposited substrates. Using the contact angles of the two test liquids $(\theta), \mathrm{SFE}$ of the carbon films was estimated using Fowkes theory ${ }^{24}$ as follows:

$$
\begin{gathered}
\frac{\gamma_{L}(\cos \theta+1)}{2}=\sqrt{\gamma_{L}^{D} \gamma_{S}^{D}}+\sqrt{\gamma_{L}^{P} \gamma_{S}^{P}}, \\
\gamma_{S}^{D}=\frac{\gamma_{L}(\cos \theta+1)^{2}}{4},
\end{gathered}
$$

where $\gamma_{L}^{D}$ and $\gamma_{L}^{P}$ are dispersive and polar components of the wetting liquid's surface tension, and $\gamma_{S}^{D}$ and $\gamma_{S}^{F}$ are dispersive and polar components of the solid's surface energy. Equation (2) is used when the wetting liquid has zero polar component (such as diiodomethane with $\gamma_{L}^{P}=0$ ) so that $\gamma_{D}^{L}=\gamma_{L}$. The total SFE of the surface is calculated as

$$
\gamma_{S}=\gamma_{S}^{P}+\gamma_{S}^{D} .
$$


Likewise, morphology of the surface was analyzed using atomic force microscopy (AFM; Park Systems XE-70; Suwon, Korea) in noncontact mode. Optical properties of the films were probed using infrared spectroscopy and Raman scattering spectroscopy.

\section{Biofilm Assay}

The biofilm formation was assessed using a wild-type $P$. aeruginosa (BIOTECH 1313, harvested from a water sample; Philippine National Collection of Microorganisms, BIOTECH, UP Los Banos) as the biofilm-forming bacterium. P. aeruginosa is a pathogen found in bacterial infestations in immune-compromised individuals and contaminated implants, and its virulence is caused mainly by enduring biofilms. ${ }^{25}$ It has been used extensively in the study of initial biofilm formation and bioremediation. ${ }^{26}$ The biofilm growth was quantified using the method developed by O'Toole. ${ }^{27}$ The bacterial specimen was inoculated in nutrient broth medium for $24 \mathrm{~h}$ at $37^{\circ} \mathrm{C}$. The overnight culture was diluted 1:100 into fresh medium and transferred to each centrifuge tube, where the glass specimen was positioned vertically. The tubes were incubated for $36 \mathrm{~h}$ at $37^{\circ} \mathrm{C}$. After incubation, tubes were washed with $0.85 \% \mathrm{NaCl}$ solution to remove loosely attached cells. The glass slides were air-dried for $12 \mathrm{hr}$. Then, the bound cells were stained with $200 \mu \mathrm{L} 0.1 \%$ crystal violet (CV) solution for $10 \mathrm{~min}$ at room temperature. Excess dye was removed by washing each tube with $200 \mu \mathrm{L} 0.85 \% \mathrm{NaCl}$ solution. For quantification, $1 \mathrm{~mL} \mathrm{30 \%}$ acetic acid was added to each tube to solubilize the $\mathrm{CV}$. We used a spectral scan with $30 \%$ acetic acid in water as a blank solution.

\section{RESULTS AND DISC USSION}

\section{A. Surface Pretreatment}

Organosilanes such as HMDSO react with various oxygen-containing faces on the glass that results in the formation of covalent bonds between oxygen and silicon. ${ }^{28}$ The acidcatalyzed hydrolysis of HMDSO with glass, as shown in Fig. 1, provides nonpolar moieties on the glass for better deposition of acetylene.

\section{B. Physic o-Chemic al Properties of Carbon Films}

The results for contact angle measurements (Fig. 2) are shown in Table 1. For water, the contact angle increased as acetylene was deposited. Meanwhile, the diiodomethane

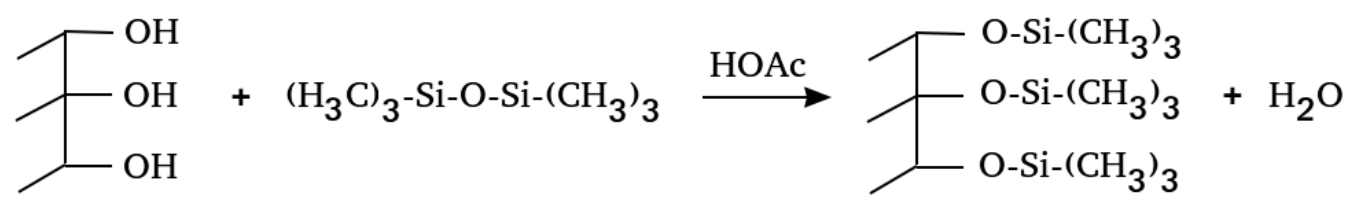

FIG. 1: Schematic representation of the surface modification of HMDSO on a glass surface 


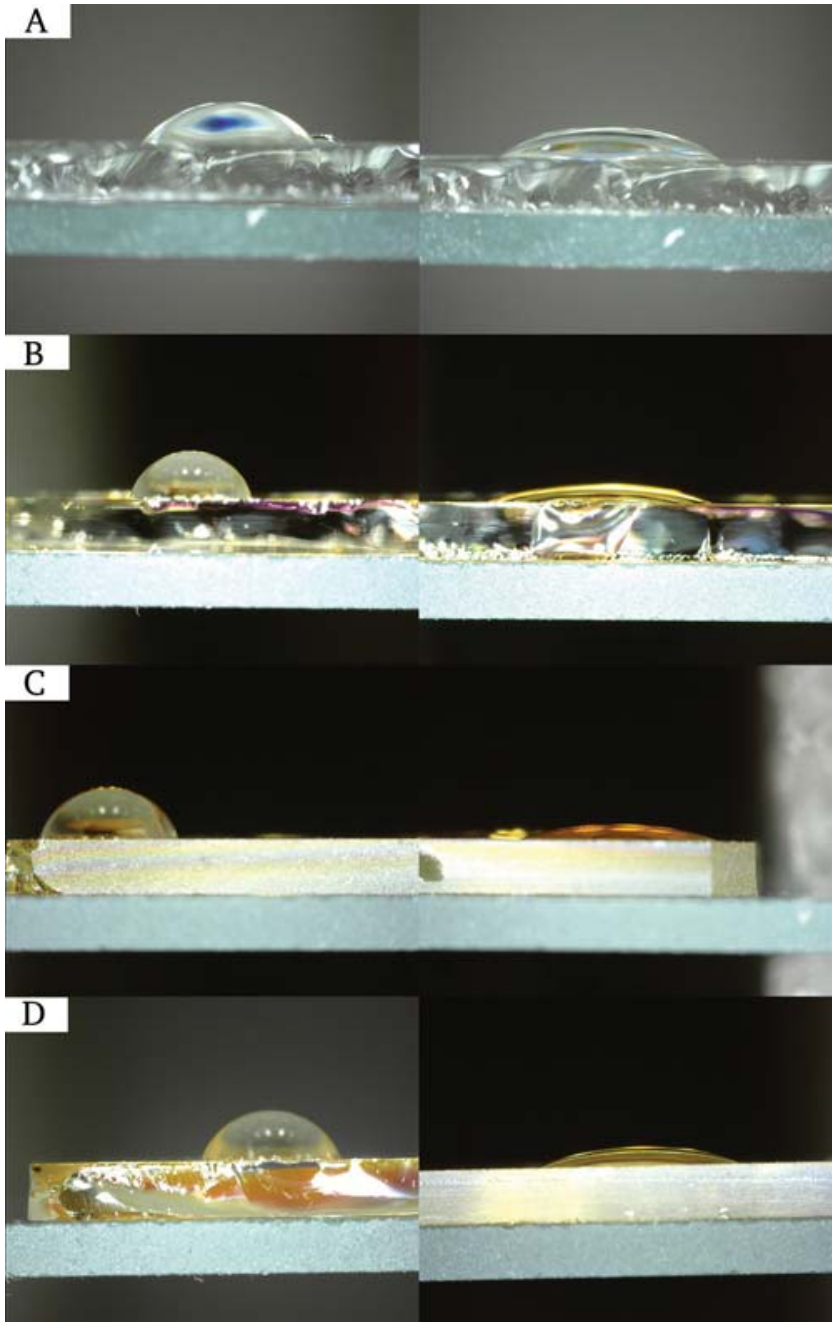

FIG. 2: Images of water (left) and diiodomethane (right) droplets on glass substrates at different treatment times: (A) $0 \mathrm{~min},(\mathrm{~B}) 1 \mathrm{~min},(\mathrm{C}) 3 \mathrm{~min}$, and (D) $5 \mathrm{~min}$

TABLE 1: Contact angle of test liquids and the SFE

\begin{tabular}{llll}
\hline $\begin{array}{l}\text { Deposition time } \\
(\mathbf{m i n})\end{array}$ & $\mathbf{H}_{\mathbf{2}} \mathbf{O}$ Contact angle $\left(^{\circ}\right)$ & $\mathbf{C H}_{\mathbf{2}} \mathbf{I}_{\mathbf{2}}$ Contact angle $\left(^{\circ}\right)$ & $\mathbf{S F E}(\mathbf{m N} / \mathbf{m})$ \\
\hline 0 & $40.12 \pm 0.90$ & $39.93 \pm 0.62$ & $61.55 \pm 0.62$ \\
1 & $73.70 \pm 1.24$ & $23.00 \pm 1.58$ & $49.67 \pm 0.65$ \\
3 & $63.97 \pm 8.36$ & $23.58 \pm 1.69$ & $53.08 \pm 3.60$ \\
5 & $70.86 \pm 1.57$ & $26.96 \pm 0.92$ & $49.48 \pm 0.66$ \\
\hline
\end{tabular}

SFE, Surface free energy.

Volume 8, Issue 1, 2018 
contact angle exhibited an opposite trend of the results obtained with water. SFE of the surfaces was computed using the values in Table 2. The deposition of acetylene on glass considerably reduced SFE from 61.5 to $49.67 \mathrm{mN} / \mathrm{m}$ for the first minute. The film deposited for $5 \mathrm{~min}$ had the lowest surface energy of $49.48 \pm 0.66 \mathrm{mN} / \mathrm{m}$, although this was still greater than the $20-30-\mathrm{mN} / \mathrm{m}$ range for minimal bacterial adhesion. Table 1 shows that the deposition of acetylene increased the hydrophobicity of the surface, thus decreasing wettability and surface energy of the glass. ${ }^{29}$

Figure 3 shows the AFM images of untreated and plasma-treated glass substrates. Table 3 shows the root-mean-square (RMS) roughness, skewness, and kurtosis of the films. The plasma-treated glass treated for 3 min shows the roughest surface, whereas

TABLE 2: Surface-tension components of the test liquids used in SFE calculation

\begin{tabular}{lcc}
\hline Test liquid & $\boldsymbol{\gamma}_{\boldsymbol{L}}^{\boldsymbol{D}}(\mathbf{m N} / \mathbf{m})$ & $\boldsymbol{\gamma}_{\boldsymbol{L}}^{\boldsymbol{P}}(\mathbf{m N} / \mathbf{m})$ \\
\hline Water $\left(\mathrm{H}_{2} \mathrm{O}\right)$ & 21.8 & 51.0 \\
Diiodomethane $\left(\mathrm{CH}_{2} \mathrm{I}_{2}\right)$ & 50.8 & 0.0 \\
\hline
\end{tabular}

SFE, surface free energy

(a)

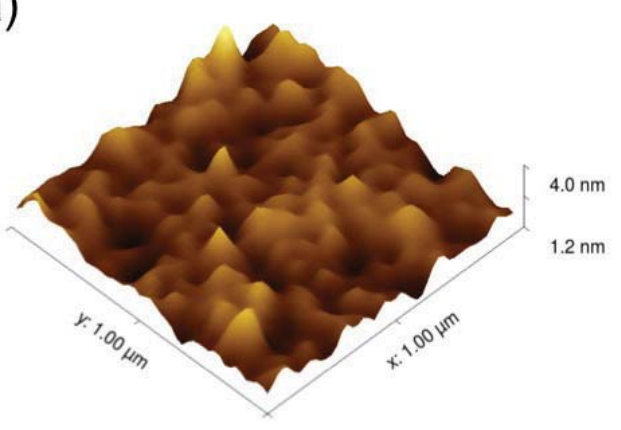

(c)

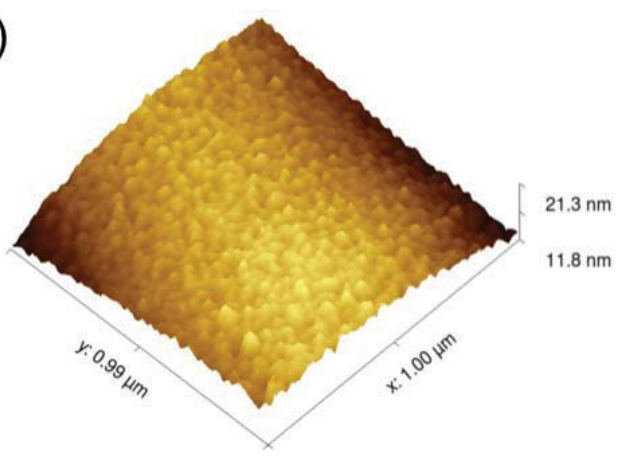

(b)

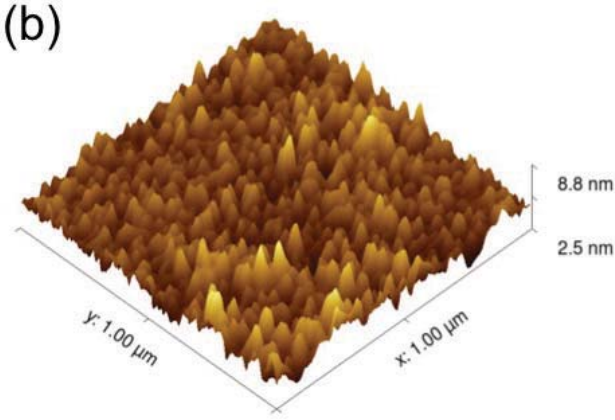

(d)

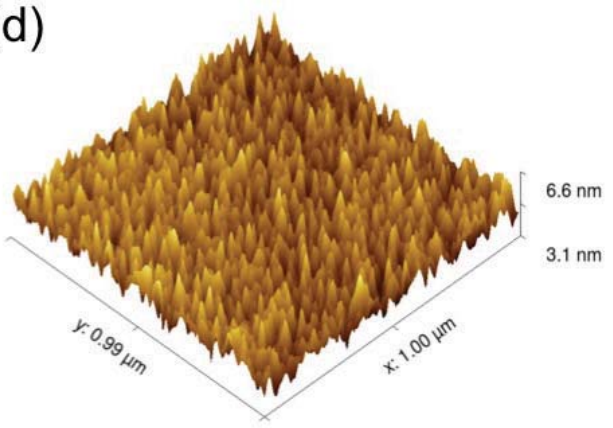

FIG. 3: AFM images of (a) a bare glass substrate and glass with acetylene deposit at exposure times of (b) $1 \mathrm{~min}$, (c) $3 \mathrm{~min}$, and (d) $5 \mathrm{~min}$ 
TABLE 3: Statistical data for surface roughness obtained by AFM

\begin{tabular}{lccc}
\hline $\begin{array}{l}\text { Deposition time } \\
\text { (min) }\end{array}$ & RMS roughness $(\mathbf{n m})$ & Skewness & Kurtosis \\
\hline 0 & 0.283 & -0.032 & 4.224 \\
1 & 1.652 & -0.198 & 4.299 \\
3 & 20.031 & 1.117 & 3.563 \\
5 & 3.629 & -5.772 & 60.767 \\
\hline
\end{tabular}

$\mathrm{AFM}$, atomic force microscopy; RMS, root mean square

those treated for 1 and $5 \mathrm{~min}$ had less roughness. The 5-min specimen had the highest kurtosis, signifying a narrow spread and highly peaked distribution, suggesting that the film may have isolated clusters of carbon deposits.

Figure 4 shows Fourier-transform infrared (FTIR) spectra of the plasma-treated glass substrates. For both 1- and 3-min deposition times, we found that bands corresponding to an aliphatic C-H stretch were present at 2934 and $2928 \mathrm{~cm}^{-1}$, respectively. Hence, carbon moieties are confirmed to be present in these films. The Si-O vibrational mode is also present at $916 \mathrm{~cm}^{-1}$ for all deposition times. Alkenyl $\mathrm{C}=\mathrm{C}$ and $\mathrm{C}=\mathrm{O}$ stretches were also present at 1653 and $1734 \mathrm{~cm}^{-1}$, respectively, and the absorption intensities increased from 1 to $3 \mathrm{~min}$, noting the increase in the $s p^{2}$ carbon cluster and carbonyl

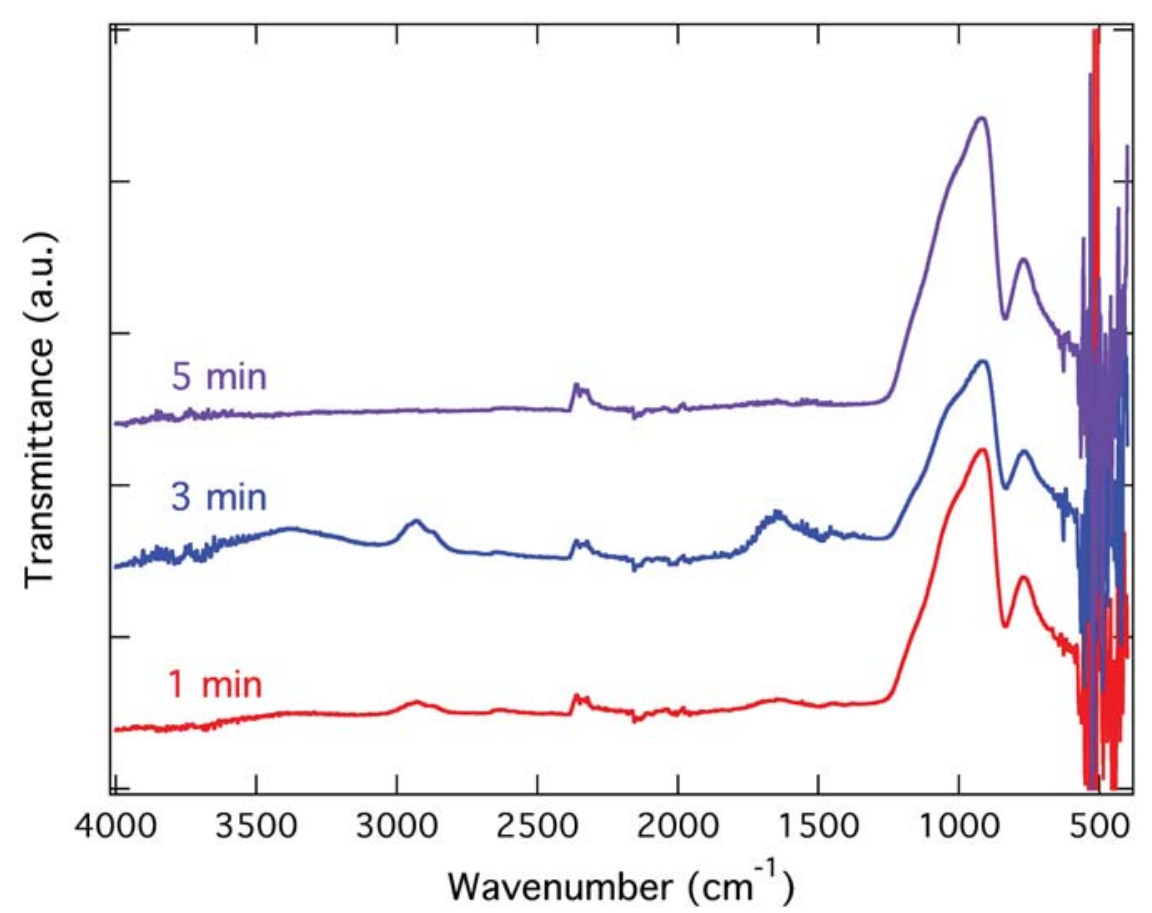

FIG. 4: FTIR spectra of acetylene-deposited glass substrates for 1-, 3-, and 5-min exposure times 
carbon coverage. An $\mathrm{O}-\mathrm{H}$ band at $3373 \mathrm{~cm}^{-1}$ is also present, and peaks at 2322 and 2359 $\mathrm{cm}^{-1}$ accounted for the adsorbed $\mathrm{CO}_{2}$ gas, possibly due to surface thermal oxidation.

The Raman spectrum provides a detailed bonding and characteristic of the carbon films. Figure 5 shows two prominent peaks: $D$ (disorder) and $G$ (graphite). The $D$ peak located at $\sim 1320 \mathrm{~cm}^{-1}$ is due to the defect-induced breathing mode of $s p^{2}$ rings of $A_{1 \mathrm{~g}}$ symmetry, ${ }^{30}$ whereas the $G$ peak at $\sim 1600 \mathrm{~cm}^{-1}$ is due to first-order scattering of the $E_{2 \mathrm{~g}}$ phonon of $s p^{2} \mathrm{C}$ atoms ${ }^{30}$ The intensity of the $D$ band is related to the size of the in-plane $s p^{2}$ domains. ${ }^{31}$ The increase in $D$-peak intensity indicates the formation of more $s p^{2}$ domains. ${ }^{32}$ The relative ratio of both peaks is a measure of the degree of disorder and is inversely proportional to the average size of the $s p^{2}$ carbon clusters. ${ }^{31,33}$ The computed ratio (Table 4) was found to be $0.7219,0.8356$, and 0.7446 for 1-, 3-, and 5-min deposition times, respectively. This indicates an initial increase in the number of $s p^{2}$ carbon (disorder on $s p^{2}$ rings) and then an increase in the number of $s p^{2}$ rings.

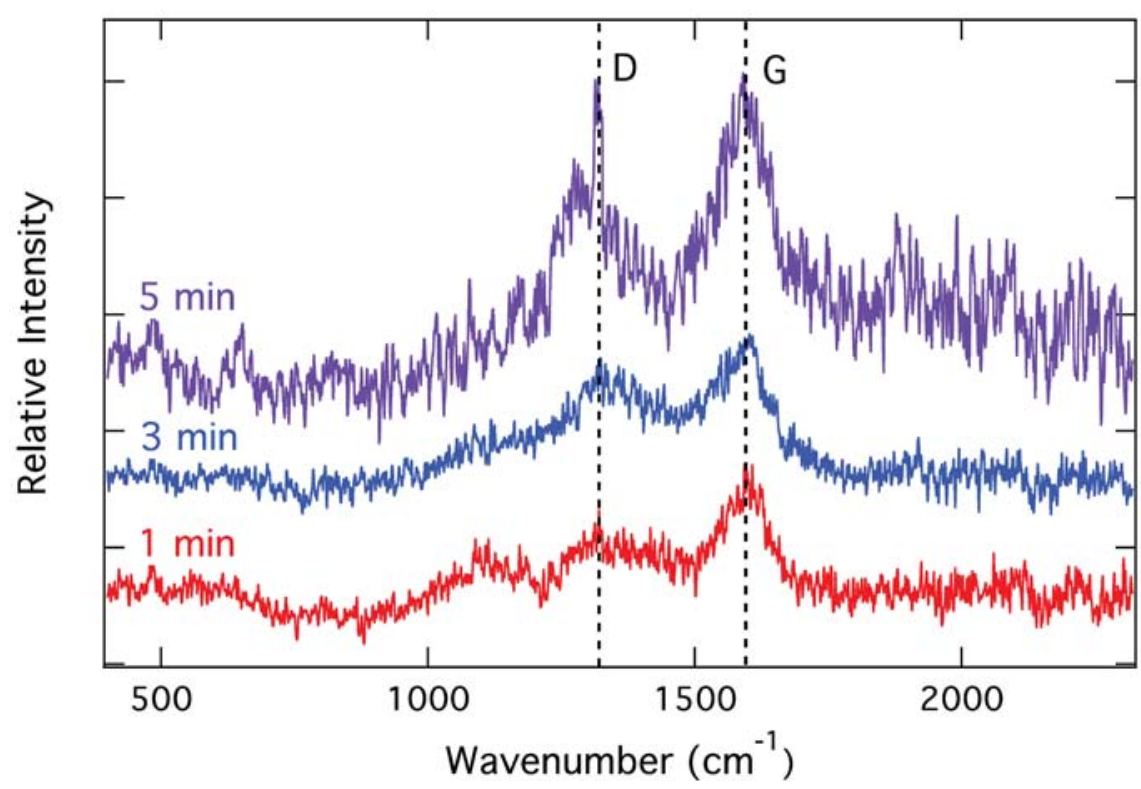

FIG. 5: Raman spectra of acetylene-deposited glass substrates for 1-, 3-, and 5-min exposure times. D, disorder; G, graphite

TABLE 4: Raman absorbance intensities and ratio

\begin{tabular}{lccc}
\hline $\begin{array}{l}\text { Deposition time } \\
(\text { min) }\end{array}$ & $\boldsymbol{I}_{\boldsymbol{D}}$ & $\boldsymbol{I}_{G}$ & $\boldsymbol{I}_{\boldsymbol{D}} / \boldsymbol{I}_{G}$ \\
\hline 1 & 102.160 & 141.523 & 0.7219 \\
3 & 125.819 & 150.582 & 0.8356 \\
5 & 209.764 & 281.719 & 0.7446 \\
\hline
\end{tabular}


From both FTIR and Raman spectroscopy results, we suggest an initial formation of graphene oxide in the 3-min deposition time, where $\mathrm{O}-\mathrm{H}$ and $\mathrm{C}=\mathrm{O}$ functionalities occur as seen in the FTIR spectra, and an increase in disorder of the hexagonal graphene layer as the number of $s p^{3}$ carbon clusters increases due to oxidation, as seen in the Raman spectra. For the 5-min deposition time, $\mathrm{O}-\mathrm{H}$ and $\mathrm{C}=\mathrm{O}$ functionalities disappeared, disorder of graphene later decreased, and the number of $s p^{2}$ clusters increased, because acetylene may have restored the carbon vacancy defect of graphene oxide. ${ }^{34}$

\section{Biofilm Assay}

A biofilm stained with $\mathrm{CV}$ provides a quantitative method of measuring the amount of cells that adhered on the glass surface. Figure 6 shows ultraviolet-visible absorbance spectra of undeposited and deposited glass substrates. The absorbance at $588 \mathrm{~nm}$ that is equivalent to the concentration of adhered cells significantly decreased on acetylenedeposited glass. Although bacterial adhesion is minimized in hydrophilic surfaces ${ }^{35}$ for hydrophobic bacteria such as $P$. aeruginosa,${ }^{15}$ the decrease in the concentration of adhered bacteria can be attributed to the decrease in surface energy. ${ }^{36}$ This is consistent with the results of Quirynen et al., wherein dental plaque formed on hydrophobic rather than hydrophilic surfaces, ${ }^{37}$ and by Everaert et al., wherein hydrophobic silicone rubber voice prostheses in laryngectomized patients developed less biofilm than a hydrophilic prothesis. ${ }^{38}$ Furthermore, rougher surfaces reduce the attachment area between particle and surface, ${ }^{39}$ thereby decreasing bacterial adhesion and surface cleanability. ${ }^{40}$

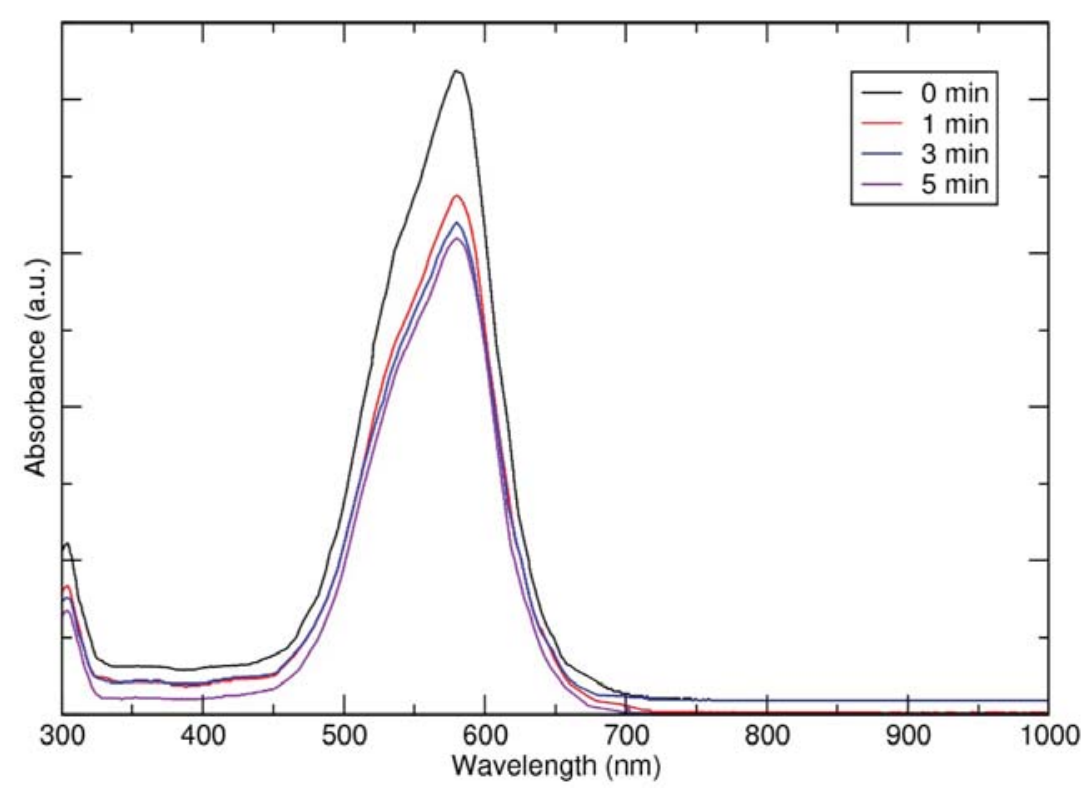

FIG. 6: Optical density obtained from cells stained with CV after incubation for $36 \mathrm{hr}$, for acetylene on glass deposited for $0,1,3$, and $5 \mathrm{~min}$

Volume 8, Issue 1, 2018 


\section{CONCLUSIONS}

We found that the deposition of acetylene successfully reduced the number of cells present in the biofilm. Contact angle and surface energy measurements showed that the acetylene-deposited glass substrates had increased hydrophobicity and decreased surface energy. AFM images showed rougher surfaces when acetylene was deposited on the substrates. FTIR and Raman spectroscopy suggested the presence of carbon in the films and indicate graphene oxide as a possible identity for the film. Further studies can be performed using X-ray diffraction measurements to confirm the structure. The biofilm assay showed a decrease in the concentration of the adhered bacteria, with the decreased adhesion attributed mainly to increased surface roughness and decreased surface energy.

\section{ACKNOWFDGMENTS}

The authors thank Aljon Francis Koji Elagado and Dr. Marco Nemesio Montaño of Seaweed Chemistry Laboratory and Pilot Plant, Marine Science Institute, University of the Philippines (UP), Diliman, for helping with the biofilm assay. M.R.V. is grateful to the UP Office of the Vice President for Academic Affairs Balik-PhD grant OVPAABPhD-2014-01 and the UP system Enhanced Creative Work and Research grant ECWRG 2016-2-096.

\section{REFERENCES}

1. Garrett TR, Bhakoo M, Zhang Z. Bacterial adhesion and biofilms on surfaces. Prog Nat Sci. 2008;18(9):1049-56.

2. Calfee DP. Crisis in hospital-acquired healthcare-associated infections. Ann Rev Med. 2012;63:359-71.

3. Schaberg DR, Culver DH, Gaynes RP. Major trends in the microbial etiology of nosocomial infection. Am J Med. 1991;91:72S-5.

4. Lower SK, Lamlertthon S, Casillas-Ituarte NN, Lins RD, Yongsunthon R, Taylor ES, DiBartola AC, Edmonson C, McIntyre LM, Reller LB, Que YA, Ros R, Lower BH, Fowler VG, Jr. Polymorphisms in bronectin binding protein A of Staphylococcus aureus are associated with infection of cardiovascular devices. Proc Natl Acad Sci. 2011;108(45):18372-7.

5. Bjarnsholt T. The role of bacterial biofilms in chronic infections. APMIS. 2013;121:1-58.

6. Heydorn A, Ersboll BK., Hentzer M, Parsek MR, Givskov M, Molin S. Experimental reproducibility in flow-chamber biofilms. Microbiology. 2000;146(10):2409-15.

7. Dalton HM, March PE. Molecular genetics of bacterial attachment and biofouling. Curr Opin Biotechnol. 1998;9(3):252-5.

8. Kjelleberg S, Molin S. Is there a role for quorum sensing signals in bacterial biofilms? Curr Opin Microbiol. 2002;5(3):254-8.

9. Zhang LH, Dong YH. Quorum sensing and signal interference: Diverse implications. Mol Microbiol. 2004;53(6):1563-71.

10. Bakke R, Trulear MG, Robinson JA, Characklis WG. Activity of Pseudomonas aeruginosa in biofilms: Steady state. Biotechnol Bioeng. 1984;26(12):1418-24.

11. Dunne WM. Bacterial adhesion: Seen any good biofilms lately? Clin Microbiol Rev. 2002;15:155-66.

12. Costerton JW, Stewart PS, Greenberg EP. Bacterial biofilms: A common cause of persistent infections. Science. 1999;284(5418):1318-22. 
13. Watnick P, Kolter R. Biofilm, city of microbes. J Bacteriol. 2000;182(10):2675-9.

14. Hall-Stoodley L, Costerton JW, Stoodley P. Bacterial biofilms: From the natural environment to infectious diseases. Nat Rev Microbiol. 2004;2:95-108.

15. Li B, Logan BE. Bacterial adhesion to glass and metal-oxide surfaces. Colloids Surf B Biointerfaces. 2004;36(2):81-90.

16. Hermansson M. The DLVO theory in microbial adhesion. Colloids Surf B Biointerfaces. 1999;14(14):105-19.

17. van Loorsdrecht MCM, Lyklema J, Norde W, Schraa G, Zehnder AJB. Electrophilic mobility and hydrophobicity as a measure to predict the initial steps of bacterial adhesion. Appl Environ Microbiol. 1987;53:1898-901.

18. Wei C, Peng KS, Hung MS. The effect of hydrogen and acetylene mixing ratios on the surface, mechanical and biocompatible properties of diamond-like carbon films. Diam Relat Mater. 2016;63: $108-14$.

19. Zhao Q, Liu Y. Modification of stainless steel surfaces by electroless Ni-P and small amount of PTFE to minimize bacterial adhesion. J Food Eng. 2006;72(3):266-72.

20. Pavlukhina SV, Kaplan JB, Xu L, Chang W, Yu X, Madhyastha S, Yakandawala N, Mentbayeva A, Khan B, Sukhishvili SA. Non-eluting enzymatic antibiofilm coatings. ACS Appl Mater Interfac. 2012;4(9):4708-16.

21. Sahal G, Nasseri B, Bilkay IS, Piskin E. Anti-biofilm effect of nanometer scale silver (NmSAg) coatings on glass and polystyrene surfaces against P. mirabilis, C. glabrata and C. tropicalis strains. J Appl Biomater Funct Mater. 2015;13(4):301-88.

22. Liu Z, Hu Y. Sustainable antibiofouling properties of thin film composite forward osmosis membrane with rechargeable silver nanoparticles loading. ACS Appl Mater Interfaces. 2016;8(33):21666-73.

23. Sun $\mathrm{H}$, Chen $\mathrm{M}$, inventors. Low temperature plasma coating for anti-biofilm formation. United States patent US 13/741,216. July 18, 2013.

24. Fowkes FM. Attractive forces at interfaces. Ind Eng Chem. 1964;56(12):40-52.

25. Høiby N, Ciofu O, Bjarnsholt T. Pseudomonas aeruginosa biofilms in cystic fibrosis. Future Microbiol. 2010;5:1663-74.

26. Brown MR, Barker J. Unexplored reservoirs of pathogenic bacteria: Protozoa and biofilms. Trends Microbiol. 1999;7(1):46-50.

27. O’Toole GA. Microtiter dish biofilm formation assay. J Vis Exp. 2011;47:2437.

28. Huang L, Nair P, Nair M, Zingaro RA, Meyers E.A. Chemical deposition of Bi2S3 thin films on glass substrates pretreated with organosilanes. Thin Solid Films. 1995;268(1):49-56.

29. Donlan RM. Biofilms: Microbial life on surfaces. Thin Solid Films. 2002;8:881-90.

30. Ferrari AC. Determination of bonding in diamond-like carbon by Raman spectroscopy. Diam Relat Mater. 2002;11(36):1053-61.

31. Guo Y, Sun X, Liu Y, Wang W, Qiu H, Gao J. One pot preparation of reduced graphene oxide (RGO) or $\mathrm{Au}(\mathrm{Ag})$ nanoparticle-RGO hybrids using chitosan as a reducing and stabilizing agent and their use in methanol electrooxidation. Carbon. 2012;50(7):2513-23.

32. Sobon G, Sotor J, Jagiello J, Kozinski R, Zdrojek M, Holdynski M, Paletko P, Boguslawski J, Lipinska L, Abramski KM. Graphene oxide vs. reduced graphene oxide as saturable absorbers for Er-doped passively mode-locked fiber laser. Opt Express. 2012;20(17):19463-73.

33. Akhavan O, Ghaderi E. Escherichia coli bacteria reduce graphene oxide to bactericidal graphene in a self-limiting manner. Carbon. 2012;50(5):1853-60.

34. Wang C, Xiao B, Ding YH. Theoretical investigation on the healing mechanism of divacancy defect in graphene growth by reaction with ethylene and acetylene. New J Chem. 2013;37:640-5.

35. Tegoulia VA, Cooper SL. Staphylococcus aureus adhesion to self-assembled monolayers: Effect of surface chemistry and fibrinogen presence. Colloids Surf B Biointerfaces. 2002;24(34):217-28.

36. Liu Y, Zhao Q. Influence of surface energy of modified surfaces on bacterial adhesion. Biophys Chem. 2005;117(1):39-45.

Volume 8, Issue 1, 2018 
37. Quirynen M, Marechal M, Busscher HJ, Weerkamp AH, Darius PL, van Steenberghe D. The influence of surface free energy and surface roughness on early plaque formation. J Clin Periodontol. 1990;17(3):138-44.

38. Everaert EPJM, Mahieu HF, Chung RPW, Verkerke GJ, van der Mei HC, Busscher HJ. A new method for in vivo evaluation of biofilms on surface-modified silicone rubber voice prostheses. Eur Arch Otorhinolaryngol. 1997;254(6):261-3.

39. Barthlott W, Neinhuis C. Purity of the sacred lotus, or escape from contamination in biological surfaces. Planta. 1997;202(1):1-8.

40. Riedewald F. Bacterial adhesion to surfaces: The influence of surface roughness. PDA J Pharm Sci Technol. 2006;60:164-71. 